\title{
Muslim Women and Politics in Cameroon
}

\author{
Fabilou \\ Department of Political Science, University of Ngaoundéré University \\ Cameroon \\ Email : fabiloul [AT] gmail.com
}

\begin{abstract}
Religion has not ceased to seize an importantplace in the political scene over the last several decades. The use of religious arguments remains a common practice among political actors. Many religious movements have seen their base and their sphere of influence consolidated or contested. Currently, the influence of religions against the oppression of women brings to mind the images of chadors, burkas, and hijabs. People frequently claim that Islam oppresses women. These accusations often result in imprisoning women.
\end{abstract}

This article will discuss the place of women in the political scene of Cameroon from an anthropological and sociohistorical perspective and, based on that approach, we will propose a modification to the status of Muslim Women in political society. This modification shall include consideration that women have been given and the way they fit into the social landscape. This is an analysis of the links which have been woven between religion and society in Cameroon.

Keywords --- Islam, women, religion, Muslimwoman

\section{INTRODUCTION}

In Cameroon, as in most developing countries, religion occupies a central place in collective psychology ${ }^{1}$. Therefore, research in Social Science gives great importance to the unders tanding of its impact on inter-individual relationships. Economic, moral and above all, identity crises contribute to making Islama growing religion ${ }^{2}$. New attempts to define faith are at the center of intellectual debates in many Muslim countries ${ }^{3}$. The question of the status of women with corollary matters such as abortion, family planning, divorce, and poly gamy are quite present in both religious and feminist circles. This article intends to analyze different obstacles to the participation of Muslim women in public life.

\section{The place of women in politics seen by the texts of Islam}

The place occupied by religion in the politics has increased continuously for many decades. The use of religious arguments in politics is an increasingly common practice in both modern and developing countries. Here, we shall make a fresh examination of Islamic texts to enlighten women's place in politics.

\subsection{The place of women in the Qur'an}

\footnotetext{
${ }^{1}$ Based on those obstacles, Cameroonian Islam is associated to "Black Islam", an expression which arose in the 1910s and was [theoretically] created by P. J. André in his book L'Islam Noir, which contributed to the study of brotherhoods in West Afric a. That discussion is followed by a study on Islam in Dahomey, Paris, by P. Geuthner, 1924. "Black Islam" is a controversial expression which designates the Islam practiced by Africans south of the Sahara. The concept of "Bkack Islam" has been a major tool in the dev elopment of French Muslim policy in Sub-Saharan Africa. The concept of "black Islam" is opposed to "white Islam", "yellow Islam" and it irrit ates or even infuriates Africans who see it as an attempt at division led by the former colonizing power.

${ }^{2}$ The rise of Is lamist movements in the Mus lim world, marked by the victory of Shia Is lamin the Iranian revolution(1979), has led many specialis ts to regard Western-style political modernization in the Muslimworld as impos sible to achieve and to conclude that Islamis incompatible with the modern world. The September 11 attacks in the United States, "in thename of Is lam", contributed to the popularization of this pers pective, which res urfaces in media reports at the calls of Bin Laden, George Bush, and countless other political figures. This perspective makes a categorical dis tinction between the Westem and Mus limworlds, and categorizes Islamas a corpus of immutable doctrines and defines it as an objective, independent force, separate from his torical and social contexts, etc. which would shape Muslims, their cultures and cultural systems, their social relationships and intellectual traditions.

${ }^{3}$ Morocco, Tunisia, Egypt, and Senegal are all examples of modern Muslim societies. We note that Saudi Arabia still remains silent even though in 2012 the King promised to bring s ome improvement to the political arena and we witnessed the participation of Saudi women for the first time in the municipal elections of 2015. Women participated as both voters and candidates.
} 
The Qur'an, as a sacred text and a primary benchmark of Is lam, contains no mention of the case of a well-defined model of political governance. Therefore, no clearly defined political sy stem is prescribed by the Qur'an. Neither are there laws or commandments which explicitly define a mode of political organization per $\mathrm{se}^{4}$. However, the Qur'an contains principles which can guide the management of politic al affairs within the community such as the principle of Shura or consultation and that of Tâ'a or respect due to elected representatives of the people (Ouloul Amri Minkoum) ${ }^{5}$. These principles are defined within the framework of global ethics. The method by which they must beapplied is not specified in Qur'anic texts. Throughout this Qur'anic explanation, we can glimpse the status of Muslim women, especially the treat ment to which they are subject in contemporary societies, including Cameroon.

The status of women in Islam is very noble. This concept has a great impact on every Muslim life. In fact, the Muslim woman, as Mother, is the first teacher in the building of society. This is true world wide.

Islam is the very first religion to have given freedom to women to directly conduct trade with the rest of society. Prior to Islam, women had to use a male tutor orguardian. Is lam has deprived women of only one "freedom": that of indulging in libertinismand vulgarity. This law applies equally to men. Indeed, Gustave Lebon expresses it best: "The merit of Islam is not only to have raised the value of women, but we add to that the fact that it is the very first religion to have done this and we can easily prove this by a survey showing that all the religions and nations which preceded the Arabs have abused women" (G. Lebon, .488).

Currently, women are able to demonstrate the tension of finding a position between the forces of traditional Islam and modernization.in a comparison of Westernization versus conservative Islam, which has no solid foundation because of the following:

- The Qur'an had given women, a higher legal status than any other religion in the world;

- A woman's fate varies fromone Muslimcountry to another;

- Until the middle of the 20th century, the ways of life in Western countries were not markedly different. Only the mobilization of women ended up making a difference. Through mobilization, women achieved the rights to vote, to own property, and to inherit, for example.

- Finally, in the difficult fight for emancipation, Muslim women's target is less religion than modern or Westernized mentality and social structures. An exegesis of the texts in the light of evolution proves to be an imperative. Hence the importance of the Ijtihad or personal effort of interpretation.

Woman is equal to man as regards responsibility toward Is lamic laws: when the conditions are fulfilled, women are bound to the same obligations as men in terms of prayer, zakat, fasting and pilg rimage. The only differenceis that women benefit, by the will of the Legislator, from certain alleviations. Thus, women are dispensed from prayer and fasting during menstruation and lochia and make up missed days of fasting only once purified. Women are equal to men conceming human nature. According to Hadith 236 of Abu Dâwud: "Women are sisters of men".

Islam regards honouring women as a sign of a healthy, accomplished and virtuous personality; (Abdur-Razaq Ibn AbdulMoushin AlBadr, 2006, 31-68.).

Women are equal to men in education. Both have the right to good education and training. Moreover, Islamconsiders the education and good care of girls as one of the causes of entry into Paradise. The Prophet Muhammad said concerning the matter, "Whoever takes care of three girls, educates them, gives them in marriage and treats them properly, will have Paradise (as a reward.)" Women are subject to the same res ponsibilities as men in terms of learning and teaching. The Prophet Mohammed said: "The seeking of knowledge is an obligation for all Muslim women and Muslim men." Women, like men, must take responsibility for reforming society by recommending good and forbidding evil.

Therefore, the Qur'an lays the ethical foundations of governance and political participation without defining a specific political system of organization. It provides moral rules that guide believers all the time and, in all contexts, concerning the exercise of political power. The Qur'an governs politics, not by legislation but through a moral system, which will correspond in the jargon of our contemporary world to the "moralization" of political life. The Qur'an specifies in several verses that those whohold power must exercise it with absolute justice and equity (Verses 4:58 and 16: 90.).

Qur'anic guidelines concerning the modalities of the representation or the exercise of political power do not specify in any part of the sacred text that political representation should be exclusively by men and that women should be excluded. On the contrary, the Qur'an uses a common language through which the two genders are challenged equally and without distinction.

\subsection{The participation of women in public life at the time of the Prophet}

\footnotetext{
${ }^{4}$ This is the true difference between what is portrayed in the media throughout political systems world wide and the Islamic political regime: Authoritarianism.

${ }^{5}$ There is a terminology consecrated by the Qur'an to designate "the leaders". Here it is used by Asma Lamrabet in her writings
} 
The Prophet Muhammad was undoubtedly one of the greatest defenders of women. All the stories of his tradition, life, deeds, and words testify to the immense respect and consideration he had for all women. Whether with his wives, daughters, or other women, the Prophet was always supportive of them. He encouraged them, freed them, and love themabove all. In one of his famous hadith, the Prophet said that Allah had made himlove women and perfumes in this life and that Salat (prayer) was the apple of his eye ${ }^{6}$. Followers of the notion of supremacy of men over women estimate that it is a right given to men by God, which enables men to enjoy the pleasure of life and relegates women to these worldly pleasures. This vision is in complete contradiction with the speech of the Prophet, to whom we attribute this quote: "Women are sisters of men."

The notation accompanying this hadith is the mention of the woman at the same time as the prayer when the latter constitutes a fundamental act of the spiritual practice of Islam ${ }^{7}$. The prophet loved women in his earthly life as he loved prayer in his spiritual life. This subtle relationship between love, happiness, and spirituality testifies to the special way in which the prophet revered women. It is a completely innovative vision of women, even revolutionary, that the Prophet brought to the midst of a tribalBedouin Society that was extremely hostile to women as Asma Lamrabet affirmed.

While women were considered most often as possessions to covet, devalued, and marginalized in a society whose patriarchy was most austere. The prophet of Is lamtells themth at he loves themas he loves prayer and that for him they embody the source of life and happiness on earth!

The Prophet fought hard so that women may freely choose their future husband, so that they are no longer subordinate to their fathers, brothers, sons, and husbands. Additionally, so that women may speak to defend themselves, express themselves, even criticize when necessary. The list of women who understood that this mes sage of freedom was central to Islam, who lived it, transmitted it, and who were the first to commit themselves to the side of the Prophet who understood and loved them, would be far too long to include here. Khadija, the wife and first companion of the Prophet Muhammad, was the first person who really protected him, appeased him and above all convinced him of the authenticity of the revelation he had received. We can mention:

Umm Salama who was his political adviser during the most difficult moments, when he finds himself alone and misunderstood by all. Aisha, the love of his life, the one who had learned from the source of prophecy what many companions failed to grasp, the one who was the guardian of his teaching.

The Prophet fought with all his strength to deliver the mes sage of Is lam, which consisted of freeing and eman cipating women, helping remove them from their condition as reclusive chattel. History bears witness to the Prophet's speeches, stories and hadith are preserved in numerous classic works, where each hadith is an act of freedomand dignity res tored to women.

According to the same authors, women are equal to men except in situations where men are "naturally" superior. Listen very well: almost every where!

Bilquis, the Queen of Sheba, is often used as a reference by those who approve of women's political participation. She is a true example of women in Is lam attaining thehighest levels of political governance. In fact, this woman is described in the Qur'an as a true democratic sovereign who was very concerned with the rules of political consultation with the representatives of her people (Quran 27:23-44). The Qur'an, through several verses, portrays Bilquis's wis domand insight and exemplifies her as a model of a just, skillful and enlightened political leader. One of the classical Muslimcommentators called her "an intelligent and wise Queen."

In fact, the Qur'an criticizes the despotism of sovereigns' through her mouth saying: "When kings enter a city, they pervert it and make its noble inhabitants the most miserable of beings and this is how 'us ually they behave."'

According to Ibn Abass, who is considered one of the most great exegetes of the Qur'an, Bilquis is the speaker in this verse but the last sentence is a response from God "This is how they us ually behave."

The Qur'an therefore confirms its rejection of despotic autocracies since it fully subscribes to Bilquis' allegation. It encourages the acceptance of shared universal values as gifts of humanity. Bilquis' remark was accepted by God as a univers al truth and her polytheism was not an obstacle to the diffusion and tran smission of this truth to all mankind through the Qur'an, monotheist holy book. ${ }^{9}$ [Note that, upon her initial exposure to Is lam, Bilquis immediately became Muslim.]

It is through these small details of great importance that we discover the infinity of divine wis dom, which has never ceased to educate believers of both genders to be open to others, to respect and live diversity as a gift from the Creator and above all to reclaim knowledge, truth, and virtue, wherever they are found, as the rights of every human being.

A certain number of exegetes, notably classical, dis parage Bilquis' contribution and refuse to see the sensitivity, the beauty and the generosity that the Qur'an employs to describe the queen as markedly different from others. The Qur'an paints a laudatory portrait of her, praises her qualities as a wise and pacifist sovereign, and subscribes to her remarks in relation to

\footnotetext{
${ }^{6}$ Hadith reported by An Nassaii, but which has often been mis interpreted by some scholars of Is lam.

${ }^{7}$ Prayer is the second pillar of Is lam

${ }^{8}$ Sayd Qutb, Tafs sir « fidilal al quran (The mention of Bilquis' reversion to Islam would make this much clearer.)

${ }^{9}$ The scholar Mohammed Amine Chen guitiaffirms: "God legitimized the as sertion of Bilquis and her dis belief was nota justification to refuse what she declared as truth": Adwaael bayane, tafssir elquran bilquran 5/1.
} 
the despotisms of certain kings. But the majority of Muslimscholars refuse to take the example of Bilquis as an argument in favour of the permis sibility for women to be heads of state.

This contradiction in the logic of Mus lim scholars who, while refusing to consider Bilquis as quoted in the Quran as a model of political leader because shewas a "disbeliever", nevertheless deduced fromher own comments a major principle major of Mus limlaw.

The scholars' deductions fromBilqu is ' political position, in addition to being erroneous, go against the Qur'anic statement which defines this woman as an example of a leader who could not have been more democratic and who transmitted to all humanity her knowledge and wis dom, considered by the Qur'anic story as universal v alues.

\section{CAMEROONIAN MUSLIM WOMEN BETWEEN FACT AND POLITICAL TRENDS}

Currently, in Cameroon, the socio-political and socio-economic reality leads Muslimwomen to get out of her "saré ${ }^{10 "}$ and fight for emancipation in all areas. However, they face traditionalist and patriarchal resis tance from men. However, the initial impetus and the spirit of the Qur'an reveal a significant emancipation of women and a clear desire to establish an egalitarian spirituality between women and men. This parity has notbeen reflected in all as pects of life for Mus limwomen, both in and out of Cameroon.

The Cameroonian Muslim woman, in order to succeed and being at the fore of society, must present herself in various domains by carrying out activities in intellectual, political, economic, social and cultural fields . ${ }^{11}$

\subsection{Barriers to the political emancipation of Muslim women in Cameroon}

The political emancipation of Muslim women in Cameroon is permanently confronted with political instability and sociological barriers. Geographic and en vironmental barriers which act to curb the ardor of Muslimwomen to participate in public life in Cameroon. This phenomenon maintains a kind of dis regard from women who often declare that they are not interested in politics. Despite their professed disinterest, women tend to have a s lightly higher rate of voting than men. Thus, Paul Lazarsfeld ${ }^{12}$ noted that women can dispense theirselves of having political opinions without disc rediting the opinion that they or others have of themselves. In other words, they exclude themselves from the debate, considering themselves illegitimate to formpolitical opinions.

The social environment in which Muslimwomen live does not allow themto express themselves as comfortably as men. It should therefore be noted that Muslim women face both traditional and popular prejudices. Beyond that, women find themselves excluded from society. Their exclus ion fromboth education and the arenas of decision making exis t apparently without worry about this embarrassing situation.

\subsubsection{Traditional and popular conceptions as barriers to the development of the Muslim woman in political life}

Exclusion is one of the themes that is at the core of numerous international debates. Indeed, modern society is globalizing and every thing that does not enter the system is considered marginal and, therefore, rejected. Whether it takes the formof segregation, discrimination, or identity crises (as in Kabylia), the problemof exclusion is more or les s pres ent at all levels of the societal and social hierarchies. Alain Touraine rightly asserts that: " nowadays, the problem is not exploitation but exclusion, therefore, the solution is to concretely create the ins truments andforms of political action that allow social integration. " (Touraine (A.), 1991)

The Mus limwoman is facing an impos sible situation where everything is concentrated in the hands of a sin gle actor who is at the same time the judge and the injured parties. In fact, we have two contradictory arguments. First, we can observe that this precarious situation often refers to customs that are foreign, even exis ting prior to Qur'anic norms, native to the Mediterranean era in general(TILLON (G. ), 1966; MERNISSI (F.), 1983; 1987; 1987 and 1991);

Conversely, Is lamic law, which has not succeeded in fully resolving either the structures of kinship and family, or the conception and practices pertaining to the control of sexuality, has changed a little bit to allow Mu slim societies to achieve legal equality of genders and to achieve significant gains in terms of the emancipation of women. This is what prompted Bourdieu to say that: "The distribution of women and men within a private space and a public space, with specific roles and predefined prerogatives, is probably one of the most ancient cleavages and one of very first factors of traditional female oppression". (Bourdieu (P.), 1990: 31)

\footnotetext{
${ }^{10}$ The word (saré) is originally fromFulani and designates the house or the domicile. It can als o refer to the woman of the house.

${ }^{11}$ We deem it inappropriate to make an incursion into the brotherly divisions because in Cameroon they are minor. Only one division can be observed: That of the Sunnis and the Shiites. The first are froman old es tablishment while the second are recent in their es tablishment and are recruited much more in the cities of Douala andFoumbot-Koutaba.

${ }^{12}$ As part of a study of voters in the United States entitled "The American Voters, "he leads this reflection.
} 
Mus lim society is characterized by segregation of public space by gender. Private space is considered as feminine and separate from public space, which is classified as masculine. Although the dichotomy between private space and public space has been questioned by many feminist anthropologis ts, arguing that it does not take into consideration the dynamics of social interaction. (Fabilou, 2010: 32)

The private vs. public dichotomy is not only present in relationships between individuals, but also in geographic sharing of space between men and women in relation to the division of labour. The spaces are therefore classified as private or public depending on the people involved and the activities taking place.

The house is the place for the well-being of the Muslim woman and the place she expresses its real meaning. A Kabyle proverb says: "The woman is the central pillar of the house; the man is the main beam". Or: " man is the outdoor lamp, while woman is the indoor lamp " (Graine Mebarka (L.), 2006). Woman gives life and prosperity to the house, and fills it. According to rural folk traditions, "It is the woman who is its soul and heart." Therefore, Woman is the soul and the heart of the house. The house and the woman are linked by a relationship full of close symbolism. One cannot be understood without the other. They complete each other.

\subsubsection{Common negative perceptions offemale leadership}

We cannot talk about the exclu sion of Muslim women from decision -making structures without referring to their exclusion from family decision-making first. Women in the Islamo-Fulani tradition, for example, are excluded from the family decision-making sphere. (Fabilou, 2010: 33) This reality is an observation made through the various family as sociations that we find in Cameroon ${ }^{13}$. Men are the most influential members of these structures and women, if present, just serve as cooks. When the question was asked to one of the association leaders, he answers that: 'the place of women is in the kitchen and not where serious things are done." 14

Through this response, we can conclude that the Cameroonian Muslim woman finds herself between two sides of a vice: the side of the family and the side of society. If she can fight for her fulfilment vis -à-vis society, her freedom vis-à-vis the family remains insecure. If we follow the result of our inquiry, we cannot guarantee woman's emergence if she does not reject tradition. Furthermore, she will remain confounded as it is so difficult to actually reject tradition. Thus, the Muslim woman cannot access decision-making at all bodies of her locality if she cannot be safe of the apathy of tradition in Cameroon. Fabilou, 2010: 34)

Among the important factors of change in the relation of domination vs. relegation existing between Muslim men and women, are poverty and weakness of economic power. Because economic strength gives women the means to property face public life, because it gives them the possibility of opening up new horizons and going beyond the limits of daily experience at home. When women find thems elves in public life, they are granted the right to flourish.

Currently, Muslimwomen most often suffer fromexclusion fromdifferent areas of social, educational and political life. In short, fromlife itself except in its most miserable form. This complicates the woman's task and makes her life les s bearable. Therefore, hope remains a mere dream, difficult to achieve, because man ins is ts on keeping control of everything without giving her the slightest chance to act in the social field. This is happening while the whole world moves towards more freedom, emancipation and equality. The world is closing on a general globalization of human rights. Women in Muslim societies in northern Cameroon, for example, are facing a very dis tressing situation in the $20^{\text {th }}$ century, finding themselves cloistered in the "saré", with weak economic power because this power is considered the prerogative of men. Woman is excluded from society by increasing poverty. In fact, Muslim women in northern Cameroon suffer fromlow education and a complete absence fromall the paths that might allow her to have a paying job.

Women play a major role in the economy, particularly in the informal sector, which contributes around $70 \%$ to the formation of the Gross Domestic Product (GDP). Their weight in the private sector increased from $24.0 \%$ in 2000 to $37.4 \%$ in $2002^{15}$. They are strongly grouped in the categories of middle managers $(25.8 \%)$ and executing agents $(21.4 \%)$ es sentially performing the tasks of secretary, teacher and nurse ${ }^{16}$. In the categ ories where women are most concentrated, the average wage income varies between 30,000 and 50,000 FCFA ${ }^{17}$.

\footnotetext{
${ }^{13}$ In this situation, the woman seems to be considered as "inferior", a concept observed in much of so -called traditionalist or extremist Islam. Because Islam in its entirety gives a place of choice for women in all their splendor, the position of women as chattel, cooks, or incompetent contradicts Is lamic teachings.

${ }^{14} \mathrm{He}$ mentioned the hadith that we quoted above which says that a community that lets itself be led by a woman is a community that is doomed to perdition and will experience no prosperity.

${ }^{15}$ Report of the Ministry of Women Promotion 2012.

${ }^{16}$ World Bank Report, 2003 on the state of world poverty.

${ }^{17}$ According to statis tics from the Minis try of Labor and Vocational Training in 2012.
} 
In the informal sector, women occupy more than $60 \%$ of production activities: dyers, uphols terers, seams tresses, basket weavers, vegetable farmers, and in services such as restaurants. However, their participation in the ag ricultural non-modem sector remains low. they are poorly represented in public service, where their weight has remained stable over time. If the presence of Muslimwomen is a minority in the formal sector, where it is fairly easy to quantify and assess their participation in development, it seems clear that they have a stronger presence in the informal sector, which is gaining momentumand currently seems essential in the socioeconomic analysis of the countries of black Africa and the entirety of the Third Wond. Indeed, since the $1990 \mathrm{~s}^{18}$, individuals have engaged in income-generating activities deemed informal because they have not been listed by the competent state bodies. In the light of daily life, it can be safely stated that women make up a considerable proportion of the population in this sector ${ }^{19}$.

\subsection{Muslim women and the challenges of political rationality}

Efforts to increase the political participation of Muslimwomen must operate both at the institutional level and at the level of social actors, in particular women's organizations. Thus, our field investigation revealed certain mechanisms for the sustainability of the political participation of Muslimwomen. The implementation of participatory mechanisms brings new players into the political game. It can also confirm traditional actors, but in new roles. This is particularly visible in terms of city policy, the implementation of which is largely based on new or already formed as sociations. The same logic of inclusion is found, for the citizens themselves, through all the devices linked to local democracy. (Sintomer (Y.) and Maillard (de) J., 2006)

Various studies show that contributing to participatory approaches increases the civic competence of thepeople involved, whether they are "ordinary citizens", activists or representatives of associations. Throughout organized meetings, these people better understand the problems at stake, the solutions available, the difficulties inherent to various decisions, the future constraints of implementing policies, etc.

Above all, they acquire knowledge of the substance of the case at hand and dis cover the relativity of scientific knowledge. Participatory democracy therefore produces discernment but also "concern", according to the formula of Jean -Jacques Rousseau.

The challenges for Muslim women to affirm themselves in local and national politics are diverse. To overcome them, they must first resist religious constraints, which allow them to unravel the mys tery buried in the secret of religion. Then, women must develop a policy that will allow them to speak and create in volvement in decision-making.

\subsubsection{Women's resistance to religious boundaries}

Resistance to religious boundaries involves raising awareness of Muslim women. Means that having a new vision of the contextual practice of Is lam. Resistance can also be achieved by re-appropriating theological sources.

In the last ten years, the question of women's participation in decision-making has become a priority in many international org anizations. Following the $4^{\text {th }}$ World Conference on Women, held in Beijing on September 15, 1995, participating states committed to guarantee women equal access and full participation in power structures and the power of decision making. Tragically, the result is that the Muslim woman has become resigned and has no politic al claims. The survey categorically denies this idea since in Morocco and Lebanon the rate of those who replied that women should occupy positions of responsibility reaches $93 \%$. This is very similar to the results of our survey, which states that $75 \%$ of the men and women interviewed believe that women should occupy positions of responsibility. Women's work, voting, and participation in society remain major demands for these women. What is happening is the genesis of a new self-awareness of the Muslim woman, of her history and of the world.

The illiteracy which is wreaking havoc in most countries of the Muslim world and which affects women far more than men, does not prevent, in civil societies, a real and completely new visibility of the Muslimwoman who is educated, asserts herself, and as sumes herself as a viable part of society (Fabilou, 2010: 47)

\footnotetext{
${ }^{18}$ With their share of economic crisis, structural adjustment programs, and other policies of restructuring African economies with disastrous consequences, the informal sector has appeared as an alternative to the formal economy, at least for the population at thebase.

${ }^{19}$ The reas on is simple:you have only to walk around our markets or travel the arteries of big cities to realize the massive presence of women, who spend their days strugg ling to find ways to support their families. This situation has alsocaptured Mus lim women, once cloistered in the "sare", to find themselves in the streets of the cities of Cameroon including Ngaoundéré, Mbé, Yaoundé, Douala, and more.
} 
More than an emotion and an identity tension; more than a classic penchant for conservativismautomatically attributed to women by classic political sociology, it is a real social phenomenon that the Muslimworld knows and that can be described as revolutionary ${ }^{20}$.

It is clear that there is a dynamic of liberation initiated by a return to religious sources. The Muslimworld is subject to a veritable earthquake which is certainly a continuation of a repetitive questioning in its history, but which is also and above all a fairly significant break with the continuous rehabilitation efforts, some innovators whosoever they are ${ }^{21}$. The continuity is due to the fact that in times of cris is, the Muslim world has always experienced upsurges and reconsiderations of thought based on the most natural dialectic. The rupture is due to the specificity of modernity which is in itself" an era of turbulence" without precedent, as described by MaxWeber ${ }^{22}$.

according to Weber, reviving the Is lamic faith consists of denouncing the mis appropriation of history by a power which imposes on our societies patriarchy and autocracy ${ }^{23}$, not only by considering them as only admis sible in matters of political management, but by holding these views as sacrosanct to the point of making it a dogmatic affair.

This implies the participation of women within the movement, in a beneficial journey, which is itself sufficiently revolutionary in a highly conservative society. This is the case of the situation of women in Fulani social structure. This participation is all the more meritorious and symbolic of a real revolution in the course of the curre nt and past Muslim world that the participation of women is desired and practiced at the highest level of the governing bodies of the movement. The basic theory advocating the salvation of our societies in crisis by a voluntary reintegration of women in the effort of ijtihad, the movement takes a sacred duty to promote women's participation first within it: "Muslim women must inquire about their rights. Conscious and well informed, she will have to claim their application. No one else can do that for them A solid foundation of material and moral rights will free her from ances tral servitudes and allow her to devote herself to herduties. The good work capable of rescuing Muslims is arduous and requires the voluntary effort of everyone, women and men side by side, challenging with other associations. (Abdessalam(Y.), 1998: 40)

It is indeed a revival of the original teaching of Is lam which teaches women to be social actors and not subject to double locking: autocracy and patriarchy. The models of the educatio nal programs of the female section ${ }^{24}$ should be close to the one of highly honourable women with a positive and remarkable personality. Women who speak, who fight, who negotiate their places in society. (Abdessalam(Y.), 1998: 45)

The study of the founding texts of Is $\operatorname{lam}^{25}$ is at odds with the restrictive ideology constructed through the ages by a body of exegetes ${ }^{26}$.

Undermined alldynamics of Islamic law. For these women, it is a matter of unearthing this dynamic, understanding of its spirit and triggering a liberating philosophy which breaks down all the locks and shackles imposed on themby accumulated masculine-focused traditions that have grown outside of Is lamthroughout Muslimhistory.

\subsubsection{Policy development and speaking out}

The development of public policy follows a number of principles. However, we will not return to these principles in this study. We will focus on the procedures that women must use to affirm themselves in public life. It's about power and speaking on one side hand participating in decision making on the other.

As part of its policy to promote women's rights in their entirety, the Ministry of Women's Affairs considers the participation of women in decision-making and their access to senior government positions among the priorities of their strategy. The number of women in the administration is increasingly high where they are present in the "feminized" sectors, namely education $^{27}$, social affairs and health in highereducation, their presence is increasing.

We notice that there is a slight breakthrough of Muslimwomen into high positions of responsibility; however, even if the number of women accessing these positions is not proportional, it is the opening of these positions which have remained

\footnotetext{
${ }^{20}$ According to Souley Mane, teacher of his tory at the University of Yaoundé (1), words collected on December 10, 2011 in Yaoundé.

${ }^{21}$ Ibid.

${ }^{22}$ Ibid.

${ }^{23}$ The situation experienced in Muslim societies around the world, including that of Cameroon and Vina Subdivision especially, has not escaped notice. A society where everything is concentrated in the hands of men and whomwomen are called upon to res pect without asking any question is not a society. It is a systemof patriarchal subjugation of women.

${ }^{24}$ To allow girls to go to school in Mus limsociety you have to think of a female section.(??)

${ }^{25}$ The two main sources of Is lam, which are the Qur'an and the Su nnah (tradition of the prophet inclu ding his words and his deeds) do not often corroborate with what we live in the field of politics and in life of everyday. This particularly pertains to the lives of women.

${ }^{26}$ Interpreters of the sacred texts of Is lam, who are in their entirety men.

${ }^{27}$ Currently, in Vina subdivision, we have only one Muslim woman occupying the function of inspector of the basic education district, while, in the educational community of women, we have more women with high qualifications and who are in Local schools and colleges.
} 
masculinized for a very long time ${ }^{28}$. These positions are important because they create a better future for women in decision making positions, better consideration of gender in national sectoral policies, and a greater presence of women in political spheres.

This breakthrough of women in occupations of professions requiring high qualifications should not mask the weakness of their presence in political decision-making positions or in senior government positions left to the discretion of the government. The high qualification of Muslim women in the labour market has notbeen reflected in the same proportions in decision-making positions, particularly at the political level.

A dynamic favourable to the integration of Muslimwomen in decision-making positions in the civil service has emerged during recent years. As an indication, we will cite the appointment of a Muslim woman as Secretary of State at the Ministry of Forests and Wild life; another as police commissioner. Elders such as ministers Yaou Aissatou, Youssouf Hadidja Alim and Haman Adama are icons who have enabled Muslimwomen to envision a clear path to success.

Except for women's as sociations, it is difficult to know the degree of effective participation of women in positions of res ponsibility. At the professional level, out of the hundreds professional as sociations in the country, no Muslim woman is president of any Professional Association, brokerage firm, or other such org anizations.

Analysis of the politicalexperience of women and the vitalenvironmental elements that determine this experie nce shows that proactive politics alone is not enough to achieve politicalequality. Several people are therefore intervening, directly or indirectly, to make gender equality tangible and effective on the political scene.

Those whocan intervenefor better participation of Muslimwomen in political life are:

\section{- Executive Power}

With its three components which are: the political will of the President of the Republic, the government, the Ministry of Women's affairs and the Family. The executive power serves as a locomotive to introduce new measures and propose new laws. It is therefore considered to be the key actor leading to the introduction of reforms leading to a fuller participation of women in political life. This is particularly true as presidential programs and national policies show a firm desire to lift more women into positions of responsibility.

\section{Political Parties}

Cameroon currently has more than three hundred political parties. Not all parties give women the same status, es pecially at the level of governing structures. Even if there are no relevant statistics, what emerges fromthe presence of women at the parliamentary level shows that political parties, except the CPDM, do not make an effort - through discriminatory measures (quota) - to propel women into political office. The political parties mention women in their programs without mentioning clear objectives, as is the case with the CPDM. The President of CPDM puts forward quantified objectives to be achieved.

At its periodic congresses, the CPDM consecrates a motion for "women and the family", the content of which is conceived by the grassroots(base) and contains objectives which are not clear. Action should be taken with political parties so that women are more present and better taken into account not only as voters but also as leaders and candidates. Indeed, the presence of women in political parties is a necessary condition for the full exercise of their citizenship, as well as for a true democratization of political participation as a whole. (Fétiha Saidi, 2001)

\section{CONCLUSION}

The Muslim woman remains confronted by the persistence of barriers which do not allow her to flourish. These barriers obstructher deployment on the political scene. However, she seems to find a place in public and political life. Even if her place in politics is threatened by persistent gravity, there remains a glimmer of hope maintained by the fact that a woman is, in one way or another, associated with the management of the city. Through this breach, she finds a number of e lements in terms of strategies to overcome the challenges of participation in political and public life. Politics is also a women's affair even if she is Mus lim. She simply needs to know how to seize the opportunities offered to her and gain her place in the sun of political and public life.

The practice of politics by Cameroonian Muslimwomen turns out to be an appreciable phenomenon. This appreciation can be seen through the various obstacles Muslimwomen encounter on the way to politicalemergence. These obstacles can be summed up in a single major area. Namely, the socio-cultural environment which, despite some progress, is unfavourable to the development of women. This environment seems to be hostile to her development with regard to religious precepts. Nevertheless, Muslimwomen have a few as sets that allow them to make their way politically and in public life.

\section{BIBLIOGRAPHY}

- $\quad$ ABDESSAlam (Y.), Islamiser la modernité, Casablanca, Al ofok impressions, 1998.

- $\quad \operatorname{ABDOU}(\mathrm{H}$.$) , les femmes et la politique au Niger, Niamey, NIN, 2000$.

- $\quad \operatorname{ACHIN}(\mathrm{C}$.) et al. Sexes, genre et politique, Paris, Economica, 2007.

\footnotetext{
${ }^{28}$ Position of secretary of state in a ministry, or as president of a board of directors.
} 
- $\quad$ ADAMA (H.) L'islam au Cameroun. Entre tradition et modernité, Paris, L’Harmattan, 2004.

- BAHOKEN (F.), De la présence camerounaise en France à «l'option diaspora » Enjeux, n² 24, 2005, pp. 7-15.

- BAYART J.-F. « Les rapports entre les Églises et l'État du Cameroun de 1958 à 1971 », Revue française d'études politiques africaines, $\mathrm{n}^{\circ} 80,1972$, pp. 79-104.

- $\quad$ BOURDIEU (P.), «La domination masculine », In Actes de la Recherche en Sciences Sociales, n 84, septembre 1990.

- CONWAY (M.), Political participation in the United States. Washington. D.C. Editorial Congressional Quarterly Inc., 2000.

- $\quad$ COULON (C.), Les musulmans et le pouvoir en Afrique noire, Paris, Karthala, 1983.

- $\quad$ COUlON (C.), Les musulmans et le pouvoir en Afrique noire, Religion et contreculture, Paris, Karthala, 1982.

- FABILOU, « La femme et la politique dans la vina : une analyse sociopolitique de la participation à la vie publique de 1992 à 2011 », Mémoire de master 2 en sociologie politique, Université de Douala, 2011.

- HERVIEU-LEGER (D.), Le pèlerin et le converti La religion en mouvement, Paris, Flammarion, 1999.

- $\quad \operatorname{KEPEL}(\mathrm{G}$.$) , Jihad. Expansion et déclin de l'islamisme, Paris, Gallimard, 2003$.

- LASSEUR M. «Religions et territoires au Cameroun. Les dimensions spatiales du pluralisme confessionnel », Thèse de doctorat en géographie, Université Paris 1-Panthéon-Sorbonnne, 2008.

- $\quad$ MERNISSI (F.), Le Harem politique : le Prophète et les femmes, Paris, Alhin Michel, 1987.

- MERNiSSI (F.), Le Monde n'est pas un harem. Paroles de femmes au Maroc, Paris A. Michel, 1991.

- MERNISSI (F.), Sexe, idéologie, islam, Paris, éd. Tierce, 1983.

- MERNISSI (F.), Sultanes oubliées : femmes chefs d'Etat en islam, Paris A. Michel 1987.

- MESSINA J.-P., VAN SLAGEREN J. Histoire du christianisme au Cameroun. Des origines à nos jours, Paris-Yaoundé, Karthala-Clé, 2005.

- $\quad$ OTAYEK (R.), SOARES B.F. (dir.) Islam and Muslim Politics in Africa, New York, Palgrave Macmillan, 2007, 280 p.

- $\quad$ OTAYEK R. (dir.) Le radicalisme islamique au sud du Sahara, Paris, Karthala, 1993.

- ROSNY (E.) «L’Afrique des migrations : les échappées de la jeunesse de Douala », Études, vol. 396, 2002, pp. 623 -633.

- $\quad$ ROY (O.), L’islam mondialisé, Paris, Éditions du Seuil, 2002.

- $\quad$ TILlON (G.), Le Harem et les cousins, Paris, éd. du Seuil, 1966. 